4

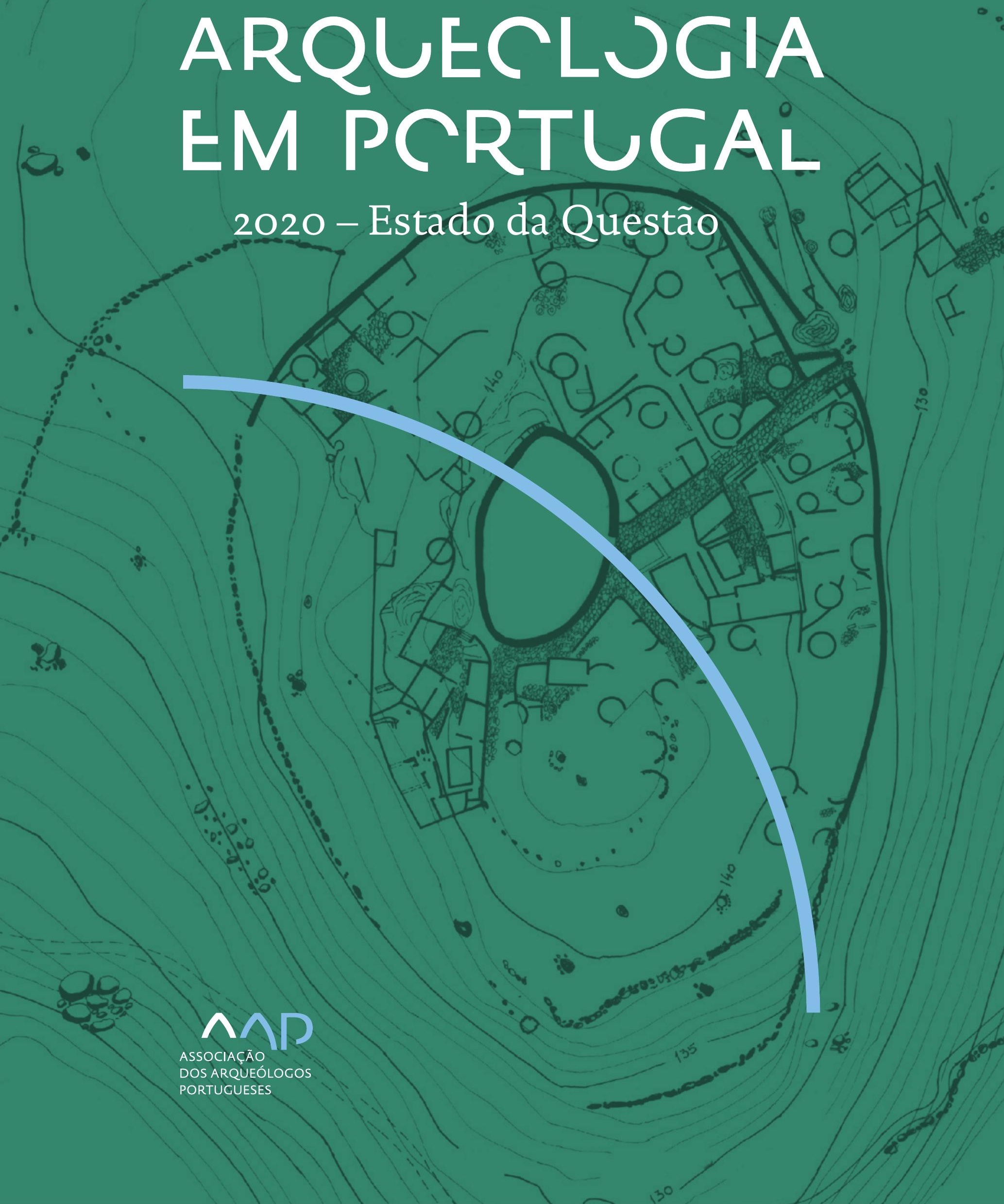


Coordenação editorial: José Morais Arnaud, César Neves e Andrea Martins Design gráfico: Flatland Design

AAP - ISBN: 978-972-9451-89-8

CITCEM - ISBN: 978-989-8970-25-1

Associação dos Arqueólogos Portugueses e CITCEM

Lisboa, 2020

O conteúdo dos artigos é da inteira responsabilidade dos autores. Sendo assim a Associação dos Arqueólogos Portugueses declina qualquer responsabilidade por eventuais equívocos ou questões de ordem ética e legal.

Desenho de capa:

Planta do castro de Monte Mozinho (Museu Municipal de Penafiel).

\section{$\hat{\wedge} \mathrm{P}$}

DOS ARQUEÓLOGOS PORTUGUESES

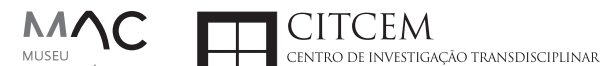
MUSEU
ARQUELLÓGICO
DO CARMO
U.PORTO

FLUP FACULDADE DE LETRAS
UNIVERSIDADE DO PORTO

Apoio

EC para a Ciência 


\section{Índice}

15 Prefácio

José Morais Arnaud

\section{Historiografia e Teoria}

17 Território, comunidade, memória e emoção: a contribuição da história da arqueologia (algumas primeiras e breves reflexões)

Ana Cristina Martins

25 Como descolonizar a arqueologia portuguesa?

Rui Gomes Coelho

41 Arqueologia e Modernidade: uma revisitação pessoal e breve de alguns aspetos da obra homónima de Julian Thomas de 2004

Vítor Oliveira Jorge

57 Dados para a História das Mulheres na Arqueologia portuguesa, dos finais do século XIX aos inícios do século XX: números, nomes e tabelas

Filipa Dimas / Mariana Diniz

73 Retractos da arqueologia portuguesa na imprensa: (in)visibilidades no feminino

Catarina Costeira / Elsa Luís

85 Arqueologia e Arqueólogos no Norte de Portugal Jacinta Bugalhão

101 Vieira Guimarães (1864-1939) e a arqueologia em Tomar: uma abordagem sobre o território e as gentes

João Amendoeira Peixoto / Ana Cristina Martins

115 Os memoráveis? A arqueologia algarvia na imprensa nacional e regional na presente centúria (2001-2019): características, visões do(s) passado(s) e a arqueologia

enquanto marca

Frederico Agosto / João Silva

129 A Evolução da Arqueologia Urbana e a Valorização Patrimonial no Barlavento Algarvio: Os casos de Portimão e Silves

Artur Mateus / Diogo Varandas / Rafael Boavida

\section{Gestão, Valorização e Salvaguarda do Património}

145 O Caderno Reivindicativo e as condições de trabalho em Arqueologia Miguel Rocha / Liliana Matias Carvalho / Regis Barbosa / Mauro Correia / Sara Simões / Jacinta Bugalhão / Sara Brito / Liliana Veríssimo Carvalho / Richard Peace / Pedro Peça / Cézer Santos

155 Os Estudos de Impacte Patrimonial como elemento para uma estratégia sustentável de minimização de impactes no âmbito de reconversões agrícolas Tiago do Pereiro

165 Salvaguarda de Património arqueológico em operações florestais: gestão e sensibilização Filipa Bragança / Gertrudes Zambujo / Sandra Lourenço / Belém Paiva / Carlos Banha / Frederico Tatá Regala / Helena Moura / Jacinta Bugalhão / João Marques / José Correia / Pedro Faria / Samuel Melro

179 Os valores do Património: uma investigação sobre os Sítios Pré-históricos de Arte Rupestre do Vale do Rio Côa e de Siega Verde José Paulo Francisco 
189 Conjugando recursos arqueológicos e naturais para potenciar as visitas ao Geoparque Litoral de Viana do Castelo (Noroeste de Portugal)

Hugo A. Sampaio / Ana M.S. Bettencourt / Susana Marinho / Ricardo Carvalhido

203 Áreas de Potencial Arqueológico na Região do Médio Tejo: Modelo Espacial Preditivo Rita Ferreira Anastácio / Ana Filipa Martins / Luiz Oosterbeek

223 Património Arqueológico e Gestão Territorial: O contributo da Arqueologia para a revisão do PDM de Avis

Ana Cristina Ribeiro

237 A coleção arqueológica do extinto Museu Municipal do Porto - Origens, Percursos e Estudos

Sónia Couto

251 Valpaços - uma nova carta arqueológica

Pedro Pereira / Maria de Fátima Casares Machado

263 Arqueologia na Cidade de Peniche

Adriano Constantino / Luís Rendeiro

273 Arqueologia Urbana: a cidade de Lagos como caso de Estudo Cátia Neto

285 Estratégias de promoção do património cultural subaquático nos Açores. O caso da ilha do Faial

José Luís Neto / José Bettencourt / Luís Borges / Pedro Parreira

297 Carta Arqueológica da Cidade Velha: Uma primeira abordagem

Jaylson Monteiro / Nireide Tavares / Sara da Veiga / Claudino Ramos / Edson Brito /

Carlos Carvalho / Francisco Moreira / Adalberto Tavares

311 Antropologia Virtual: novas metodologias para a análise morfológica e funcional Ricardo Miguel Godinho / Célia Gonçalves

\section{Didáctica da Arqueologia}

327 Como os projetos de Arqueologia podem contribuir para uma comunidade culturalmente mais consciente Alexandra Figueiredo / Claúdio Monteiro / Adolfo Silveira / Ricardo Lopes

337 Educação Patrimonial - Um cidadão esclarecido é um cidadão ativo! Ana Paula Almeida

351 A aproximação da Arqueologia à sala de aula: um caso de estudo no $3^{\circ}$ ciclo do Ensino Básico Luís Serrão Gil

363 Arqueologia 3.o - Pensar e comunicar a Arqueologia para um futuro sustentável Mónica Rolo

377 “Conversa de Arqueólogos" - Divulgar a Arqueologia em tempos de Pandemia Diogo Teixeira Dias

389 Escola Profissional de Arqueologia: desafios e oportunidades Susana Nunes / Dulcineia Pinto / Júlia Silva / Ana Mascarenhas

399 Os Museus de Arqueologia e os Jovens: a oferta educativa para o público adolescente Beatriz Correia Barata / Leonor Medeiros

411 O museu universitário como mediador entre a ciência e a sociedade: o exemplo da secção de arqueologia no Museu de História Natural e da Ciência da Universidade do Porto (MHNC-UP)

Rita Gaspar 
421 Museu de Lanifícios: Real Fábrica de Panos. Atividades no âmbito da Arqueologia Beatriz Correia Barata / Rita Salvado

427 Arqueologia Pública e o caso da localidade da Mata (Torres Novas) Cláudia Manso / Ana Rita Ferreira / Cristiana Ferreira / Vanessa Cardoso Antunes

431 Do sítio arqueológico ao museu: um percurso (também) didático Lídia Fernandes

447 Estão todos convidados para a Festa! E para dançar também... O projecto do Serviço Educativo do Museu Arqueológico do Carmo na $5^{\underline{a}}$ Edição da Festa da Arqueologia Rita Pires dos Santos

459 O “Clã de Carenque”, um projeto didático de arqueologia Eduardo Gonzalez Rocha

469 Mediação cultural: peixe que puxa carroça nas Ruínas Romanas de Troia Inês Vaz Pinto / Ana Patrícia Magalhães / Patrícia Brum / Filipa Santos

481 Didática Arqueológica, experiências do Projeto Mértola Vila Museu Maria de Fátima Palma / Clara Rodrigues / Susana Gómez / Lígia Rafael

\section{Arte Rupestre}

497 Os inventários de arte rupestre em Portugal Mila Simões de Abreu

513 O projeto FIRST-ART - conservação, documentação e gestão das primeiras manifestações de arte rupestre no Sudoeste da Península Ibérica: as grutas do Escoural e Maltravieso Sara Garcês / Hipólito Collado / José Julio García Arranz / Luiz Oosterbeek / António Carlos Silva / Pierluigi Rosina / Hugo Gomes / Anabela Borralheiro Pereira / George Nash / Esmeralda Gomes / Nelson Almeida / Carlos Carpetudo

523 Trabalhos de documentação de arte paleolítica realizados no âmbito do projeto PalæoCôa André Tomás Santos / António Fernando Barbosa / Luís Luís / Marcelo Silvestre / Thierry Aubry

537 Imagens fantasmagóricas, silhuetas elusivas: as figuras humanas na arte do Paleolítico Superior da região do Côa Mário Reis

$55^{1}$ Os motivos zoomórficos representados nas placas de tear de Vila Nova de São Pedro (Azambuja, Portugal) Andrea Martins / César Neves / José M. Arnaud / Mariana Diniz

571 Arte Rupestre do Monte de Góios (Lanhelas, Caminha). Síntese dos resultados dos trabalhos efectuados em 2007-2009 Mário Varela Gomes

599 Gravuras rupestres de barquiformes no Monte de S. Romão, Guimarães, Noroeste de Portugal Daniela Cardoso

613 Círculos segmentados gravados na Bacia do Rio Lima (Noroeste de Portugal): contributos para o seu estudo Diogo Marinho / Ana M.S. Bettencourt / Hugo Aluai Sampaio

631 Equídeos gravados no curso inferior do Rio Mouro, Monção (NW Portugal). Análise preliminar Coutinho, L.M. / Bettencourt, A.M.S / Sampaio, Hugo A.S

645 Paletas na Arte Rupestre do Noroeste de Portugal. Inventário preliminar Bruna Sousa Afonso / Ana M. S. Bettencourt / Hugo A. Sampaio 


\section{Pré-História}

661 O projeto Miño/Minho: balanço de quatro anos de trabalhos arqueológicos Sérgio Monteiro-Rodrigues / João Pedro Cunha-Ribeiro / Eduardo Méndez-Quintas / Carlos Ferreira / Pedro Xavier / José Meireles / Alberto Gomes / Manuel Santonja / Alfredo Pérez-González

677 A ocupação paleolítica da margem esquerda do Baixo Minho: a indústria lítica do sítio de Pedreiras 2 (Monção, Portugal) e a sua integração no contexto regional Carlos Ferreira / João Pedro Cunha-Ribeiro / Sérgio Monteiro-Rodrigues / Eduardo Méndez-Quintas / Pedro Xavier / José Meireles / Alberto Gomes / Manuel Santonja / Alfredo Pérez-González

693 O sítio acheulense do Plistocénico médio da Gruta da Aroeira Joan Daura / Montserrat Sanz / Filipa Rodrigues / Pedro Souto / João Zilhão

703 As sociedades neandertais no Barlavento algarvio: modelos preditivos com recurso aos SIG

Daniela Maio

715 A utilização de quartzo durante o Paleolítico Superior no território dos vales dos rios Vouga e Côa

Cristina Gameiro / Thierry Aubry / Bárbara Costa / Sérgio Gomes / Luís Luís / Carmen Manzano / André Tomás Santos

733 Uma perspetiva diacrónica da ocupação do concheiro do Cabeço da Amoreira (Muge, Portugal) a partir da tecnologia lítica Joana Belmiro / João Cascalheira / Célia Gonçalves

745 Novos dados sobre a Pré-história Antiga no concelho de Palmela. A intervenção arqueológica no sítio do Poceirão I

Michelle Teixeira Santos

757 Problemas em torno de Datas Absolutas Pré-Históricas no Norte do Alentejo Jorge de Oliveira

771 Povoamento pré-histórico nas áreas montanhosas do NO de Portugal: o Abrigo 1 de Vale de Cerdeira Pedro Xavier / José Meireles / Carlos Alves

783 Apreciação do povoamento do Neolítico Inicial na Baixa Bacia do Douro. A Lavra I (Serra da Aboboreira) como caso de estudo Maria de Jesus Sanches

797 O Processo de Neolitização na Plataforma do Mondego: os dados do Sector C do Outeiro dos Castelos de Beijós (Carregal do Sal)

João Carlos de Senna-Martinez / José Manuel Quintã Ventura / Andreia Carvalho / Cíntia Maurício

823 Novos trabalhos na Lapa da Bugalheira (Almonda, Torres Novas) Filipa Rodrigues / Pedro Souto / Artur Ferreira / Alexandre Varanda / Luís Gomes / Helena Gomes / João Zilhão

837 A pedra polida e afeiçoada do sítio do Neolítico médio da Moita do Ourives (Benavente, Portugal)

César Neves

857 Casal do Outeiro (Encarnação, Mafra): novos contributos para o conhecimento do povoamento do Neolítico final na Península de Lisboa.

Cátia Delicado / Carlos Maneira e Costa / Marta Miranda / Ana Catarina Sousa

873 Stresse infantil, morbilidade e mortalidade no sítio arqueológico do Neolítico Final/ Calcolítico ( $4^{\circ}$ e $3^{\circ}$ milénio a.C.) do Monte do Carrascal 2 (Ferreira do Alentejo, Beja) Liliana Matias de Carvalho / Sofia N. Wasterlain 
885 Come together: O Conjunto Megalítico das Motas (Monção, Viana do Castelo) e as expressões Campaniformes do Alto Minho Ana Catarina Basílio / Rui Ramos

899 Trabalhos arqueológicos no sítio Calcolítico da Pedreira do Poio Carla Magalhães / João Muralha / Mário Reis / António Batarda Fernandes

913 O sítio arqueológico de Castanheiro do Vento. Da arquitectura do sítio à arquitectura de um território João Muralha Cardoso

925 Estudo zooarqueológico das faunas do Calcolítico final de Vila Nova de São Pedro (Azambuja, Portugal): Campanhas de 2017 e 2018 Cleia Detry / Ana Catarina Francisco / Mariana Diniz / Andrea Martins / César Neves / José Morais Arnaud

943 As faunas depositadas no Museu Arqueológico do Carmo provenientes de Vila Nova de São Pedro (Azambuja): as campanhas de 1937 a 1967 Ana Catarina Francisco / Cleia Detry / César Neves / Andrea Martins / Mariana Diniz / José Morais Arnaud

959 Análise funcional de material lítico em sílex do castro de Vila Nova de S. Pedro (Azambuja, Portugal): uma primeira abordagem Rafael Lima

971 O recinto da Folha do Ouro 1 (Serpa) no contexto dos recintos de fossos calcolíticos alentejanos

António Carlos Valera / Tiago do Pereiro / Pedro Valério / António M. Monge Soares

\section{Proto-História}

987 Produção de sal marinho na Idade do Bronze do noroeste Português. Alguns dados para uma reflexão

Ana M. S. Bettencourt / Sara Luz / Nuno Oliveira / Pedro P. Simões / Maria Isabel C. Alves / Emílio Abad-Vidal

1001 A estátua-menir do Pedrão ou de São Bartolomeu do Mar (Esposende, noroeste de Portugal) no contexto arqueológico da fachada costeira de entre os rios Neiva e Cávado Ana M. S. Bettencourt / Manuel Santos-Estévez / Pedro Pimenta Simões / Luís Gonçalves

1015 O Castro do Muro (Vandoma/Baltar, Paredes) - notas para uma biografia de ocupação da Idade do Bronze à Idade Média

Maria Antónia D. Silva / Ana M. S. Bettencourt / António Manuel S. P. Silva / Natália Félix

1031 Do Bronze Final à Idade Média - continuidades e hiatos na ocupação de Povoados em Oliveira de Azeméis João Tiago Tavares / Adriaan de Man

1041 As faunas do final da Idade do Bronze no Sul de Portugal: leituras desde o Outeiro do Circo (Beja)

Nelson J. Almeida / Íris Dias / Cleia Detry / Eduardo Porfírio / Miguel Serra

1055 A Espada do Monte das Oliveiras (Serpa) - uma arma do Bronze Pleno do Sudoeste Rui M. G. Monge Soares / Pedro Valério / Mariana Nabais / António M. Monge Soares

1065 São Julião da Branca (Albergaria-a-Velha) - Investigação e valorização de um povoado do Bronze Final

António Manuel S. P. Silva / Paulo A. P. Lemos / Sara Almeida e Silva / Edite Martins de Sá

1083 Do castro de S. João ao Mosteiro de Santa Clara: notícia de uma intervenção arqueológica, em Vila do Conde Rui Pinheiro 
1095 O castro de Ovil (Espinho), um quarto de século de investigação - resultados e questões em aberto

Jorge Fernando Salvador / António Manuel S. P. Silva

1111 O Castro de Salreu (Estarreja), um povoado proto-histórico no litoral do Entre Douro e Vouga

Sara Almeida e Silva / António Manuel S. P. Silva / Paulo A. P. Lemos / Edite Martins de Sá

1127 Castro de Nossa Senhora das Necessidades (Sernancelhe): uma primeira análise artefactual Telma Susana O. Ribeiro

${ }_{1141}$ A cividade de Bagunte. O estado atual da investigação Pedro Brochado de Almeida

1153 Zoomorfos na cerâmica da Idade do Ferro no NW Peninsular: inventário, cronologias e significado Nuno Oliveira / Cristina Seoane

1163 Vasos gregos em Portugal: diferentes maneiras de contar a história do intercâmbio cultural na Idade do Ferro

Daniela Ferreira

1175 Os exotica da necrópole da Idade do Ferro do Olival do Senhor dos Mártires (Alcácer do Sal) no seu contexto regional

Francisco B. Gomes

\section{Antiguidade Clássica e Tardia}

1191 O uso de madeira como combustível no sítio da Quinta de Crestelos (Baixo Sabor): da Idade do Ferro à Romanização Filipe Vaz / João Tereso / Sérgio Simões Pereira / José Sastre / Javier Larrazabal Galarza / Susana Cosme / José António Pereira / Israel Espi

1207 Cultivos de Época Romana no Baixo Sabor: continuidade em tempos de mudança? João Pedro Tereso / Sérgio Simões Pereira / Filipe Santos / Luís Seabra / Filipe Vaz

1221 A casa romana na Hispânia: aplicação dos modelos itálicos nas províncias ibéricas Fernanda Magalhães / Diego Machado / Manuela Martins

1235 As pinturas murais romanas da Rua General Sousa Machado, n. ${ }^{5}$ 1, Chaves José Carvalho

1243 Trás do Castelo (Vale de Mir, Pegarinhos, Alijó) - Uma exploração agrícola romana do Douro

Tony Silvino / Pedro Pereira

1255 A sequência de ocupação no quadrante sudeste de Bracara Augusta: as transformações de uma unidade doméstica Lara Fernandes / Manuela Martins

1263 Os Mosaicos com decoração geométrica e geométrico-vegetalista dos sítios arqueológicos da área do Conuentus Bracaraugustanus. Novas abordagens quanto à conservação, restauro, decoração e datação Maria de Fátima Abraços / Licínia Wrench

1277 “Casa Romana” do Castro de São Domingos (Cristelos, Lousada): Escavação, Estudo e Musealização Paulo André de P. Lemos

1291 A arqueobotânica no Castro de Guifões (Matosinhos, Noroeste de Portugal): O primeiro estudo carpológico

Luís Seabra / Andreia Arezes / Catarina Magalhães / José Varela / João Pedro Tereso 
1305 Um Horreum Augustano na Foz do Douro (Monte do Castelo de Gaia, Vila Nova de Gaia) Rui Ramos

1311 Ponderais romanos na Lusitânia: padrões, formas, materiais e contextos de utilização Diego Barrios Rodríguez

1323 Um almofariz centro-itálico na foz do Mondego

Marco Penajoia

1335 Estruturas romanas de Carnide - Lisboa Luísa Batalha / Mário Monteiro / Guilherme Cardoso

1347 O contexto funerário do sector da "necrópole NO" da Rua das Portas de S. Antão (Lisboa): o espaço, os artefactos, os indivíduos e a sua interconectividade na interpretação do passado Sílvia Loja, José Carlos Quaresma, Nelson Cabaço, Marina Lourenço, Sílvia Casimiro, Rodrigo Banha da Silva, Francisca Alves-Cardoso

${ }_{1361}$ Povoamento em época Romana na Amadora - resultados de um projeto pluridisciplinar Gisela Encarnação / Vanessa Dias

1371 A Arquitectura Residencial em Mirobriga (Santiago do Cacém): contributo a partir de um estudo de caso Filipe Sousa / Catarina Felício

${ }_{1385}$ O fim do ciclo. Saneamento e gestão de resíduos nos edifícios termais de Mirobriga (Santiago do Cacém)

Catarina Felício / Filipe Sousa

1399 Balsa, Topografia e Urbanismo de uma Cidade Portuária Vítor Silva Dias / João Pedro Bernardes / Celso Candeias / Cristina Tété Garcia

1413 No Largo das Mouras Velhas em Faro (2017): novas evidências da necrópole norte de Ossonoba e da sua ocupação medieval Ricardo Costeira da Silva / Paulo Botelho / Fernando Santos / Liliana Nunes

1429 Instrumentos de pesca recuperados numa fábrica de salga em Ossonoba (Faro) Inês Rasteiro / Ricardo Costeira da Silva / Paulo Botelho

1439 A Necrópole Romana do Eirô, Duas Igrejas (Penafiel): intervenção arqueológica de 2016 Laura Sousa / Teresa Soeiro

1457 Ritual, descarte ou afetividade? A presença de Canis lupus familiaris na Necrópole Noroeste de Olisipo (Lisboa)

Beatriz Calapez Santos / Sofia Simões Pereira / Rodrigo Banha da Silva / Sílvia Casimiro / Cleia Detry / Francisca Alves Cardoso

1467 Dinâmicas económicas em Bracara na Antiguidade Tardia Diego Machado / Manuela Martins / Fernanda Magalhães / Natália Botica

1479 Cerâmicas e Vidros da Antiguidade Tardia do Edifício sob a Igreja do Bom Jesus (Vila Nova de Gaia) Joaquim Filipe Ramos

1493 Novos contributos para a topografia histórica de Mértola no período romano e na Antiguidade Tardia Virgílio Lopes

\section{8. Época Medieval}

1511 Cerâmicas islâmicas no Garb setentrional "português": algumas evidências e incógnitas Constança dos Santos / Helena Catarino / Susana Gómez / Maria José Gonçalves / Isabel Inácio / Gonçalo Lopes / Jacinta Bugalhão / Sandra Cavaco / Jaquelina Covaneiro / Isabel Cristina Fernandes / Ana Sofia Gomes 
1525 Contributo para o conhecimento da cosmética islâmica, em Silves, durante a Idade Média Rosa Varela Gomes

1537 Yábura e o seu território - uma análise histórico-arqueológica de Évora entre os séculos VIII-XII José Rui Santos

1547 A encosta sul do Castelo de Palmela - resultados preliminares da escavação arqueológica Luís Filipe Pereira / Michelle Teixeira Santos

1559 A igreja de São Lourenço (Mouraria, Lisboa): um conjunto de silos e de cerâmica medieval islâmica

Andreia Filipa Moreira Rodrigues

1571 O registo material de movimentações populacionais no Médio Tejo, durante os séculos XII-XIII. Dois casos de "sunken featured buildings", nos concelhos de Cartaxo e Torres Novas Marco Liberato / Helena Santos / Nuno Santos

1585 O nordeste transmontano nos alvores da Idade média. Notas para reflexão Ana Maria da Costa Oliveira

1601 Sepulturas escavadas na rocha do Norte de Portugal e do Vale do Douro: primeiros resultados do Projecto SER-NPVD

Mário Jorge Barroca / César Guedes / Andreia Arezes / Ana Maria Oliveira

1619 "Portucalem Castrum Novum" entre o Mediterrâneo e o Atlântico: o estudo dos materiais cerâmicos alto-medievais do arqueossítio da rua de D. Hugo, nํ. 5 (Porto) João Luís Veloso

1627 A Alta Idade Média na fronteira de Lafões: notas preliminares sobre a Arqueologia no Concelho de Vouzela

Manuel Luís Real / Catarina Tente

1641 Um conjunto cerâmico medieval fora de portas: um breve testemunho aveirense Susana Temudo

${ }_{1651}$ Os Lóios do Porto: uma perspetiva integrada no panorama funerário da Baixa Idade Média à Época Moderna em meios urbanos em Portugal

Ana Lema Seabra

1659 O Caminho Português Interior de Santiago como eixo viário na Idade Média Pedro Azevedo

1665 Morfologia Urbana: Um exercício em torno do Castelo de Ourém André Donas-Botto / Jaqueline Pereira

1677 Intervenção arqueológica na Rua Marquês de Pombal/Largo do Espírito Santo (Bucelas, Loures)

Florbela Estêvão / Nathalie Antunes-Ferreira / Dário Ramos Neves / Inês Lisboa

1691 O Cemitério Medieval do Poço do Borratém e a espacialidade funerária na cidade de Lisboa Inês Belém / Vanessa Filipe / Vasco Noronha Vieira / Sónia Ferro / Rodrigo Banha da Silva

1705 Um Espaço Funerário Conventual do séc. XV em Lisboa: o caso do Convento de São Domingos da Cidade Sérgio Pedroso / Sílvia Casimiro / Rodrigo Banha da Silva / Francisca Alves Cardoso

\section{9. Época Moderna e Contemporânea}

1721 Arqueologia Moderna em Portugal: algumas reflexões críticas em torno da quantificação de conjuntos cerâmicos e suas inferências históricas e antropológicas Rodrigo Banha da Silva / André Bargão / Sara da Cruz Ferreira

1733 Faianças de dois contextos entre os finais do século XVI e XVIII do Palácio dos Condes de Penafiel, Lisboa

Martim Lopes / Tomás Mesquita 
1747 Um perfil de consumo do século XVIII na foz do Tejo: O caso do Mercado da Ribeira, Lisboa Sara da Cruz Ferreira / Rodrigo Banha da Silva / André Bargão

1761 Os Cachimbos dos Séculos XVII e XVIII do Palácio Mesquitela e Convento dos Inglesinhos (Lisboa)

Inês Simão / Marina Pinto / João Pimenta / Sara da Cruz Ferreira / André Bargão / Rodrigo Banha da Silva

1775 "Tomar os fumos da erua que chamão em Portugal erua sancta». Estudo de Cachimbos provenientes da Rua do Terreiro do Trigo, Lisboa

Miguel Martins de Sousa / José Pedro Henriques / Vanessa Galiza Filipe

1787 Cachimbos de Barro Caulínitico da Sé da Cidade Velha (República de Cabo Verde)

Rodrigo Banha da Silva / João Pimenta / Clementino Amaro

1801 Algumas considerações sobre espólio não cerâmico recuperado no Largo de Jesus (Lisboa) Carlos Boavida

1815 Adereços de vidro, dos séculos XVI-XVIII, procedentes do antigo Convento de Santana de Lisboa (anéis, braceletes e contas)

Joana Gonçalves / Rosa Varela Gomes / Mário Varela Gomes

1837 Da ostentação, luxo e poder à simplicidade do uso quotidiano: arqueologia e simbologia de joias e adornos da Idade Moderna Portuguesa Jéssica Iglésias

1849 Os amuletos em Portugal - dos objetos às superstições: o coral vermelho Alexandra Vieira

1865 Cerâmicas de Vila Franca de Xira nos séculos XV e XVI Eva Pires

1879 «Não passa por teu o que me pertence». Marcas de individualização associadas a faianças do Convento de Nossa Senhora de Aracoeli, Alcácer do Sal Catarina Parreira / Íris Fragoso / Miguel Martins de Sousa

1891 Cerâmica de Leiria: alguns focos de produção

Jaqueline Pereira / André Donas-Botto

1901 Os Fornos na Rua da Biquinha, em Óbidos Hugo Silva / Filipe Oliveira

1909 A casa de Pêro Fernandes, contador dos contos de D. Manuel I: o sítio arqueológico da Silha do Alferes, Seixal (século XVI) Mariana Nunes Ferreira

1921 O Alto da Vigia (Sintra) e a vigilância e defesa da costa Alexandre Gonçalves / Sandra Santos

1937 O contexto da torre sineira da Igreja de Santa Maria de Loures Paulo Calaveira / Martim Lopes

1949 A Necrópole do Hospital Militar do Castelo de São Jorge e as práticas funerárias na Lisboa de Época Moderna Susana Henriques / Liliana Matias de Carvalho / Ana Amarante / Sofia N. Wasterlain

1963 SAND - Sarilhos Grandes Entre dois Mundos: o adro da Igreja e a Paleobiologia dos ossos humanos recuperados

Paula Alves Pereira / Roger Lee Jesus / Bruno M. Magalhães

1975 Expansão urbana da vila de Cascais no século XVII e XVIII: a intervenção arqueológica na Rua da Vitória no 15 a 17

Tiago Pereira / Vanessa Filipe

1987 Novos dados para o conhecimento do Urbanismo de Faro em época Moderna Ana Rosa 
1995 Um exemplo de Arqueologia Urbana em Alcoutim: o Antigo Edifício dos CTT Marco Fernandes / Marta Dias / Alexandra Gradim / Virgílio Lopes / Susana Gómez Martínez

2007 Palácio dos Ferrazes (Rua das Flores/Rua da Vitória, Porto): a cocheira de Domingos Oliveira Maia

Francisco Raimundo

2021 As muitas vidas de um edifício urbano: História, Arqueologia e Antropologia no antigo Recreatório Paroquial de Penafiel Helena Bernardo / Jorge Sampaio / Marta Borges

2035 O convento de Nossa Senhora da Esperança de Ponta Delgada: o contributo da arqueologia para o conhecimento de um monumento identitário João Gonçalves Araújo / N’Zinga Oliveira

2047 Arqueologia na ilha do Corvo... em busca da capela de Nossa Senhora do Rosário Tânia Manuel Casimiro / José Luís Neto / Luís Borges / Pedro Parreira

2059 Perdidos à vista da Costa. Trabalhos arqueológicos subaquáticos na Barra do Tejo Jorge Freire / José Bettencourt / Augusto Salgado

2071 Arqueologia marítima em Cabo Verde: enquadramento e primeiros resultados do projecto CONCHA

José Bettencourt / Adilson Dias / Carlos Lima / Christelle Chouzenoux / Cristóvão Fonseca / Dúnia Pereira / Gonçalo Lopes / Inês Coelho / Jaylson Monteiro / José Lima / Maria Eugénia Alves / Patrícia Carvalho / Tiago Silva

2085 Trabalhos arqueológicos na Cidade Velha (Ribeira Grande de Santiago, Cabo Verde): reflexões sobre um projecto de investigação e divulgação patrimonial André Teixeira / Jaylson Monteiro / Mariana Mateus / Nireide Tavares / Cristovão Fonseca / Gonçalo C. Lopes / Joana Bento Torres / Dúnia Pereira / André Bargão / Aurélie Mayer / Bruno Zélie / Carlos Lima / Christelle Chouzenoux / Inês Henriques / Inês Pinto Coelho / José Lima / Patrícia Carvalho / Tiago Silva

2103 A antiga fortificação de Quelba / Khor Kalba (E.A.U.). Resultados de quatro campanhas de escavações, problemáticas e perspectivas futuras Rui Carita / Rosa Varela Gomes / Mário Varela Gomes / Kamyar Kamyad

2123 Colónias para homens novos: arqueologia da colonização agrária fascista no noroeste ibérico Xurxo Ayán Vila / José Mạ . Señorán Martín 


\title{
ZOOMORFOS NA CERÂMICA DA IDADE DO FERRO NO NW PENINSULAR: INVEN- TÁRIO, CRONOLOGIAS E SIGNIFICADO
}

\author{
Nuno Oliveira ${ }^{1}$, Cristina Seoane ${ }^{2}$
}

\begin{abstract}
RESUMO
Nos estudos de cerâmica da Idade do Ferro no noroeste da Península Ibérica, destacam-se um determinado número de peças que apresentam decoração com motivos zoomórficos. Provavelmente sua relativa raridade neste período, onde predominam os motivos geométricos, se torne algo de especial interesse como instrumento social e ideológico para o estudo da sociedade.

O objetivo deste estudo foi o de realizar o primeiro inventário deste tipo de motivos associado ao seu contexto geográfico, à sua cronologia, funcionalidade, valor social e simbólico dessa representação na sociedade que a produziu. Após organização dos dados obtidos, esses elementos foram comparados com a decoração em metais e outros materiais.
\end{abstract}

Palavras-Chave: Coleção cerâmica, Motivos figurativos, Decoração estampada, Cronologia, Interpretação.

\begin{abstract}
In the Iron Age ceramics studies on the NW of Iberian Peninsula, had number of pieces that feature decoration with zoomorphic motifs stand out. Probably their relative rarity within the ceramics in this period, where geometric motifs dominate, become of special interest as a social and ideological instrument for the society. The aim of this study was to carry out the first inventory of this type of motifs associated with its geographical context and its chronology and the functionality, social and symbolic value of this representation in that society. After organizing the data obtained, these elements were compared with the decoration in metals and other fabrics.
\end{abstract}

Keywords: Ceramic collection, Figurative motifs, Stamped decoration, Chronology, Interpretation.

\section{INTRODUÇÃO}

Os estudos cerâmicos da Idade do Ferro do Noroeste Peninsular efetuados nos últimos 50 anos procuraram como principais abordagens a sistematização das características morfológicas e tecnológicas destes produtos artesanais, o que possibilitou a formulação de tipologias representativas desse período (SILVA, 1986; REY CASTIÑEIRA, 1991). Com base nesses estudos a investigação da cerâmica foi avançando ao longo do tempo, dando aos arqueólogos uma excelente de base de trabalho para as mais di- versas amplitudes territoriais. As combinações desses trabalhos com investigações mais recentes tornaram possível o estudo dos pormenores de todo o repertório cerâmico, incluído o que se procurou realizar neste artigo.

A decoração da cerâmica dos castros da Idade do Ferro conta com um amplo percurso desde diferentes perspetivas (CALO, 1999; REY CASTIÑEIRA, 1998), entre as quais se destaca o trabalho sobre cerâmica decorada por estampilha de E. Rodríguez Puentes (1986), estudo que teve muito peso no decorrer deste trabalho. Com efeito, a tese de doutoramento

\footnotetext{
1. Este trabalho foi realizado no decorrer da bolsa de doutoramento com a referência SFRH/BD/138105/2018, concedida pela Fundação da Ciência e Tecnologia. Instituição à qual agradecemos todo o apoio. Agradece-se ainda o apoio do Lab2PT, Universidade do Minho.;ntco_arque@sapo.pt.

2. Grupo de Estudo para Prehistoria do NO Ibérico - Arqueoloxía, Antigüidade e Territorio (GEPN-AAT);

crisseoanenovo@gmail.com.
} 
de G. Cabanillas de la Torre (2015) que engloba a estampagem em toda a Europa Atlântica, apresenta uma sistematização de alguns dos motivos decorativos que recolhemos neste artigo, o qual nos serviu de base para realizar a nossa base de dados.

Tomando como ponto de partida os trabalhos referenciados, além de muitos outros, associando o trabalho próprio e direto sobre as cerâmicas, levaram a observar a recorrente presença de motivos decorativos com formas zoomórficas por todo o NW Peninsular durante a Idade do Ferro.

Estes motivos contrastam com motivos geométricos que são abundantes desde da Idade do Bronze e durante toda a Idade do Ferro nesta área geográfica. Decerto, para os autores deste estudo é possível que a grande particularidade e escassez destes motivos zoomórficos seja também pelo facto de se ter dado pouco destaque estes motivos na literatura arqueológica até ao momento. Quer pela sua raridade nos espólios cerâmicos desta cronologia ou também pelas dificuldades dos estudos cerâmicos derivadas tanto à sua grande fragmentação, além de que em muitas ocasiões, estes não serem devidamente difundidos, nem são facilmente acessíveis aos investigadores por outras razões.

Aliás, este interesse por estas representações zoomórficas e a sua raridade talvez tenha várias razões de índole social e mesmo simbólicas que até agora não tinham sido consideradas.

Com efeito, os objetivos deste trabalho passaram desde logo por elaborar o primeiro inventário (o mais exaustivo e sistemático possível) deste tipo de motivos, associados com o seu contexto geográfico tanto à macro como à microescala. Mas a investigação requereu de seguida a observação das formas e/ ou tipologias cerâmicas previamente estabelecidas (MARTINS, 1987; REY CASTIÑEIRA, 1991; SILVA, 1986) em que estas decorações ocorrem, em que lugar do corpo dos recipientes se colocam, em que cronologias se inserem, quando foi possível, e finalmente, talvez o mais difícil, tentar compreender a sua funcionalidade, valor social e/ou simbólico que estas representações zoomórficas poderiam possuir e que só são entendidas seio de uma dada cultura e que neste momento nos escapa à nossa compreensão. Além destes objetivos foi ainda tido em conta a comparação com os materiais metálicos - quer em bronze (SILVA, 1986; FERNÁNDEZ, 2003; REY CASTIÑEIRA, 2005a), quer em ouro (BALSEIRO, 1994; PÉREZ, 1980) - e finalmente em último lugar apresentamos ainda exemplos de gravuras em lajes de pedra que formam parte dos espólios materiais de alguns castros do NW (FIGUEIREDO e NEVES, 2005; MEIJIDE, et al., 2009). Estes são elementos materiais que se empregam como apoio tanto a nível cronológico como simbólico e/ou cultural na hora de interpretar a importância que estes elementos guardam para as populações da Idade do Ferro no NW peninsular.

\section{METODOLOGIA}

No que diz respeito aos aspetos metodológicos que foram necessários para levar a cabo este trabalho, é de destacar que foi essencial elaborar um catálogo com todas as ocorrências de decoração de tipo zoomorfo na cerâmica. Para realizar esta compilação foi necessária tanto uma revisão bibliográfica extensa, como recorrer a alguns museus e profissionais da arqueologia na procura de fotografias ou mesmo desenhos de fragmentos que apresentassem estes motivos decorativos. Neste processo foram tidos em conta sobretudo os motivos decorativos que, sem sombra de dúvida, remetessem para ictiomorfos, ornitomorfos e quadrúpedes, que são os motivos decorativos que os autores vinham observando já algum tempo e que eram os que ocorriam em maior número. Em relação aos peixes, e sobretudo, às aves, optou-se por dividir estas representações em dois grupos: um primeiro mais próximo da realidade e com semelhanças evidentes com estes animais e um outro grupo mais abstrato, mas cuja forma remete para um tipo de animal em específico. Foram descartados aqueles motivos que, tradicionalmente, se vinham a identificar com aves como são as diferentes representações das séries de SSS estampadas, mas estas são descartadas deste trabalho por possuírem especificidades muito variadas e uma realidade complexa. De facto, este tipo de decoração merece um tratamento monográfico e específico para a sua sistematização e interpretação iconográfica.

Relativamente às fontes bibliográficas, consideraram-se as sínteses existentes para as bacias dos rios Minho (SILVA, 1986; REY CASTIÑEIRA, 1991, 1996, 2005b, 2014; SILVA, 2006),), do Lima (ALMEIDA, 1990), do Cávado (MARTINS, 1990; BETTENCOURT 1999, 2000), do Ave (DINIS, 1993); ou do Barbantiño (ÁLVAREZ GONZÁLEZ, 2019); estudos monográficos de sítios (AYÁN VILA, 2012a, 2012b; CONCHEIRO COELLO, 2008; DINIS, 2001; 
SILVA, 1997) e áreas concretas com a da Rías Baixas da Galiza (REY CASTIÑEIRA, 1990-1991).

Ainda foi necessário recorrer a de diferentes intervenções arqueológicas de sítios ainda inéditos ou cujas publicações apenas remetiam aos seus materiais.

Estas investigações foram muito importantes, posto que recolhem as primeiras compilações de alguns motivos zoomórficos, adicionando-os em mapas de distribuição de sítios que permaneciam inéditos. Todas estas e outras leituras venham a completar os dados aportados pelas mencionadas teses de licenciatura de E. Rodríguez Puentes (1986) e de doutoramento de G. Cabanillas de la Torre (2015) e J. Rey Castiñeira (1991), nas que as duas autoras e o autor fazem um percurso quer regional - no caso do primeiro e da terceira - quer suprarregional - no caso da segunda.

Além deste trabalho de recolha bibliográfica foi tido em conta o estudo direto e exaustivo, sempre que for possível, de novas coleções e contactos com museus ou colegas de profissão, que incidiram sobretudo, em povoados da bacia do rio Lima, ou das Rías Baixas, além das bacias dos rios Minho e Barbantiño na Galiza, além de outras localizações.

De todo este esforço de recompilação de informação por estes meios, conseguimos que fossem considerados 34 sítios com cerâmicas que apresentam motivos zoomórficos, repartidos em 16 assentamentos da Idade do Ferro para a área da Galiza, 4 para Astúrias e 1 em León e 12 para o norte de Portugal (Fig.1). Por último, em termos da metodologia de trabalho, os dados obtidos foram georreferenciados na plataforma IDEPatri (ABAD et al. 2011) o que possibilitou estabelecer a distribuição e dispersão geográfica dos materiais, diferenciados por motivos assim como comprovar as possíveis concorrências dos distintos motivos nos mesmos sítios e/ou se descrevem territórios ou se circunscrevem a uma área oleira das já definidas (REY CASTIÑEIRA, 1991, 1995, 2011) em particular. E também permite conhecer os limites que marcam este tipo de peças enquanto à sua distribuição.

No fim foi tentado, numa perspetiva mais global, compreender e relacionar a realidade existente nos metais dessa região onde são representados zoomorfos, procurando apresentar exemplos de peças e em que zonas dessas peças essa decoração por zoomorfos surge. Além dos metais foram consideradas as manifestações ao nível da arte rupestre inserível na proto-história da região. Procurou-se dessa forma as possíveis conotações sociais e simbólicas que teriam estes motivos zoomorfos partilhados: na cerâmica, nos metais e nas gravuras móveis.

\section{ZOOMORFOS NA CERÂMICA: AVES, PEIXES E CAVALOS}

O conjunto de dados analisados permitiu dividir os motivos zoomorfos em três grandes grupos: 1. os que representaram animais que voam; 2. os que evidenciam animais terrestres, como os equídeos e 3. os que reproduzem animais aquáticos, como os peixes. $\mathrm{Na}$ sua maioria, com a exceção dos motivos que apontam para animais terrestres, a decoração aqui em análise é produzida a partir de um estilete previamente produzido, em osso, madeira ou metal, o que tornaria os motivos a apresentar todos iguais mediante a preparação e aplicação desse selo com o desenho desejado. Esta pré-elaboração do motivo a criar e a imprimir sobre a peça requer uma considerável preparação tanto na conceção como na elaboração da peça final. No caso específico dos exemplares que apresentam quadrúpedes, a decoração é exclusivamente produzida através da impressão ou por incisão. Isto poderá ficar a dever-se ao facto de ir desenhando na peça este tipo de animal de modo manual, do que por produzir através de um estilete uma estampa de grande dimensão (Fig. 2).

Quanto a zoomorfos que se podem incluir os ornitomorfos e os ictiomorfos somam o maior número de exemplares registados neste trabalho e que, normalmente são acompanhados por caneluras incisas, por aplicações plásticas através de cordões lisos, ocorrendo inclusivamente com outras estampagens diferentes como combinações de círculos concêntricos, séries de SSS, etc.

Como podemos observar no mapa (Fig. 1), na atual Galiza os zoomorfos, sobretudo os peixes, concentram-se nas Rías Baixas, aparecendo fundamentalmente nos conhecidos tipos xerra -jarro- tipo "Toralla”, vasos de dimensões relativamente pequenas e pensadas para conter líquidos e com as paredes muito finas, e nas vasilhas de bordo engrossado tipo "Cíes", que são recipientes de grandes ou medianas dimensões destinadas provavelmente a armazenagem, bem de líquidos ou sólidos. São estas últimas as que se associam com as asas das formas conhecidas como crateriformes (REY CASTIÑEIRA, 2019) e que amossam decoração na cara exterior do lábio, 
em ocasiões com estas estampilhas zoomórficas, fundamentalmente peixes. Estas peças aparecem em castros coma o do Neixón Grande (Boiro, A Coruña), Illa de Toralla (Vigo, Pontevedra) ou o de Hortas/Cíes (Vigo, Pontevedra), entre outros vários. Também concorrem estas tipologias na região do noroeste de Portugal, como é o caso do Castro de Santo António (Oliveira e Bettencourt, 2020), onde foram registados zoomorfos aquáticos (peixes).

No caso das aves, concentram-se sobretudo na bacia do rio Minho e em parte da área Bracarense, em peças de perfil em S suave, é dizer, em vasos de bordo arredondado, colo alto e estrangulado, corpo curto, bojudo e esbelto e fundo plano de dimensões medias ou pequenas. Não obstante, para a região norte de Portugal nota-se uma preferência clara pelo uso de potinhos/púcaros para este género de decoração. É de destacar que são as aves mais esquemáticas as que se atopam na área mais oriental do NW como são Asturias ou Castilla y León. Em esta área a sua distribuição é em áreas de bacias de importantes cursos fluviais coma os rios Narcea, Nalón, Navia ou Eo, caso dos castros de Chao Samartín (Grandas de Salime, Asturias), Campa Torres (Gijón, Asturias) ou Llagú (Oviedo, Asturias), por exemplo.

No caso dos quadrúpedes, poucos são os motivos identificados neste estudo, somente dois possíveis casos na Galiza e outros dois em Portugal. Em todos os casos esta decoração foi efetuada por incisão e impressão. Estes motivos surgem em paredes que sugerem ser de formas com alguma dimensão, por exemplo de potes com mais de $20 \mathrm{~cm}$ de diâmetro e em vasilhas de tipo "Cíes". Em termos gerais, os quadrúpedes encontram-se dispersos, na área da ria de Vigo e na área entre as bacias dos rios Cávado e Ave. No caso dos motivos aquáticos, como são os, peixes, parece existir uma clara concentração na área mais próxima ao Atlântico, caso tanto da área das Rías Baixas (coma nos castros de Fozara ou Montealegre) como dos povoados no noroeste português (caso dos castros de S. Paio ou do Alto do Coto da Pena). Finalmente, os zoomorfos que apresentam aves encontram-se dispersos por todo o território em análise, contudo é necessário fazer uma ressalva: a quantidade e diversidade deste tipo de zoomorfo é bastante densa, o que em próximos trabalhos terá a devida atenção. Contudo, é necessário salvaguardar um aspeto importante: em muitos casos não foi possível identificar a tipologia de peça a que poderia pertencer. Isto porque variados motivos, ou a fon- te bibliográfica não é exaustiva a ponto de afirmar a tipologia, ou por outro lado o fragmento é de tal forma diminuto que não é possível saber a que tipo cerâmico se poderia aportar.

\section{ZOOMORFOS NOUTROS SUPORTES DA IDADE DO FERRO DO NW PENINSULAR}

A interpretação dos motivos representados foi tentada com base nas restantes materialidades existentes na Idade do Ferro do NW que apresentam motivos similares, bem gravados, tanto em relevo como em repuxados. Tal é o caso de alguns motivos na ourivesaria (diademas, torques, brincos, etc.) (BALSEIRO GARCÍA, 1994; LADRA FERNÁNDEZ, 2011; PÉREZ OUTEIRIÑO, 1980), em objetos metálicos de bronze (fíbulas, conteiras de bainha, etc.) (SILVA, 1986; FERNÁNDEZ CARBALLO, 2003; REY CASTIÑEIRA, 2005a) em elementos arquitetónicos (umbrais, lintéis, etc.) (ARIZAGA CASTRO et al., 2006) ou placas móveis com gravuras, quer na Galiza como no Norte de Portugal (SILVA, 1986; FERNÁNDEZ CARBALLO, 2003; REY CASTIÑEIRA, 2005a). Encontraram-se, ainda, equídeos gravados no NW, quer na sua área mais ocidental quer na mais oriental, assim como inúmeras placas móveis na área mais oriental com peixes também na oriental (MEIJIDE CAMASELLE et alli, 2009; NEVES, et al., 2015). Relativamente à ourivesaria, é necessário destacar, em primeiro lugar, o exemplar conhecido como Diadema de Moñes (GARCÍA VUELTA et al., 2001; SCHATTNER, 2012), uma peça singular da Idade do Ferro. Data de entre os séc. II a I a.C., e na qual está representada claramente uma cena ligada a uma celebração, onde se observam vários caldeirões, provavelmente sítulas (SEOANE, 2018), vários antropomorfos a cavalo e a pé e na que estão representadas três famílias distintas de animais: peixes, aves e cavalos. Desta peça note-se um aspeto curioso, posto que um dos fragmentos regista aves a alimentar-se de peixe e que alguns dos antropomorfos contam com uma cabeça de ave.

No que diz respeito à representação de quadrúpedes que aparecem fundamentalmente nos conhecidos como bronzes com motivos de sacrifício (ARMADA PITA, GARCÍA VUELTA, 2003). Em estes machados de bronze concorrem habitualmente os protomos dos machados - habitualmente um bovino ou ovicaprino - encabeçando uma procissão de animais quadrúpedes tanto selvagens - caso do javali - como 
domésticos - com a dos suínos ou os ovicaprinos e inclusivamente algum antropomorfo (ARMADA PITA, GARCÍA VUELTA, 2003).

Além destes exemplares é necessário fazer menção ao carro votivo de Vilela (Paredes) (SILVA, 1986) no qual surge uma espécie de procissão com vários antropomorfos apeados e nos dois extremos da peça temos uma parelha de bois.

Quanto a animais presentes em elementos arquitetónicos destaca-se o exemplar da pedra talhada e decorada procedente de um castro e que na atualidade está reutilizada na capela de Formigueiro (Chaos de Amoeiro, Ourense) neste caso temos apenas animal representado. Este alto-relevo contem uma narração na que participam un únicoantropomorfo montado num cavalo, e que aparece acompanhado aparentemente por outros quatro cavalos não montados junto com outros motivos decorativos mui próprios do NW (ARIZAGA CASTRO, et alli, 2006).

No que diz respeito a gravuras em rocha há a registar vários exemplares em vários locais. Destacamos desde logo as placas móveis com animais gravados do sítio do Castelinho (Felgar, Torre de Moncorvo), na qual se encontram placas gravadas com animais selvagens e domésticos, como os javalis, ou o cavalo, que pode aparecer com um antropomorfo montado (numa única placa, podendo representar uma cena de caça), numa outra placa surge um antropomorfo com uma lança, a apontar para aquilo que poderá ser um javali, e ainda um antropomorfo armado com uma espécie de espada embainhada e com uma lança em posição de tiro (Laje 1 do Castelinho). O Castelinho é um local com uma cronologia datável de forma geral e impressa durante a Idade do Ferro (NEVES, et al., 2015) além deste sítio aludimos a um outro que é o caso do Castro de Formigueiros (Samos, Lugo) onde foram detetadas, in situ, várias placas gravadas, no chão, com cavalos e peixes. Neste caso a datação do povoado será por volta do séc. III - II a.C. (MEJIDE CAMESELLE et alli, 2009), da qual deverá datar, provavelmente, a produção destas gravuras, em tudo semelhantes aquelas imagens produzidas sobre a cerâmica. Por último, estão as gravuras em placas do castro do Chao Samartín (Grandas de Salime, Asturias), lugar no que se localizam gravuras unicamente de cavalos (VILLA VALDEÉS, 2010-2012). E também as gravuras localizadas no Castelón de Coaña (Coaña, Asturias), nas que se representam o que parecem ser cervos (VILLA VALDEÉS, 2010-2012).

\section{ICONOGRAFIA ZOOMORFA: ALGUMAS CONSIDERAÇÕES FINAIS}

Estas peças profusamente decoradas que estiveram sob análise são produzidas para serem vistas, posto que estes desenhos são realizados nas partes mais visíveis dos vasos. Estas decorações encontram-se na área externa do lábio, passando pelo ombro, e chegando a toda a pança. Além disso, nota-se que as peças decoradas com zoomorfos são acompanhadas de outro tipo de motivos elaborados mediante diferentes técnicas como a incisão, a impressão, a aplicação plástica ou até outros elementos estampados, tornado as peças esteticamente muito apelativas.

Com efeito, no nosso entender não seria apenas o gosto estético o que estaria na origem da produção destas peças, senão talvez a representação de animais importantes para estas comunidades devido a razões de carácter social, simbólico e/o cultural.

Os diferentes contextos e matérias onde estes motivos ocorrem indiciam o seu carácter e poder comunicacional dentro duma comunidade, a sua capacidade para narrar uma outra história. Assim como possibilitam colocar a hipótese de que os recipientes decorados com estes motivos de carácter excecional, é possível que fossem usados em contextos de exceção e em ações de grande valor social e simbólico, ou simplesmente estão feitos para serem vistos.

Acreditamos, pois, que cada imagem gravada, que seria compreensível para uma comunidade e uma entidade cultural determinada, e que fora de aí poderia não ser entendida. Além disso, o trabalho que é necessário para elaborar uma peça tão preenchida com decoração e na que há que talhar um selo previamente, é muito possível que isto não seria apenas por motivos estéticos, mas também por motivos sociais, simbólicos e/ou culturais. A questão encontra-se em tentar perceber o porquê desta relação com o mundo animal e a várias espécies sobretudo no caso das aves e dos peixes.

Ora, a preocupação figurativa destas peças, poderá ser um produto da forma de olhar, imaginar, e representar muito específicos. Estas imagens zoomorfas não seriam produtos estáticos, não têm apenas um significado, mas provavelmente muitos significados que seriam negociados a para e passo na vivência social. Isto aplicado à realidade Vaccea, mas que nos serve aqui também. Assim, estas imagens na cerâmica poderiam ser uma espécie de mensagem que transportaria consigo uma dada informação que 
todos no seio daquela sociedade percecionavam recreavam e representaria parte da sua cosmovisão. É de salientar que, na sua esmagadora maioria são retratados animais selvagens e não animais domesticados pelas comunidades da Proto-história.

Nenhum trabalho no capítulo do estudo de materiais é feito sem que existam algumas dificuldades. Ora, por muitas ocasiões um dos aspetos mais complexos de se estudar a cerâmica decorada é o facto de que em muitos casos esta se encontra muito fragmentada, o que está muito vinculado à sua completa localização em ambientes habitacionais. Esta alta fragmentação é que não permitiu, por variadas vezes, compreender a que tipologia de peça previamente estabelecida pertenceria.

Além disso, muitas vezes o motivo é tão diminuto ou se encontra tão degradado que não é tão percetível, por isso condiciona a seleção de material para este trabalho, pelo que apenas foram escolhidos aqueles que indubitavelmente fizessem lembrar a algum animal, deixando fora os mais abstratos e complexos de tratar.

Finalmente, tendo em conta o inventário realizado, a conclusão mais clara é que, na sua grande maioria, as decorações por zoomorfos encontram-se em recipientes para conter líquidos, ou seja, potes e potinhos, Xerras tipo "Toralla” e vasilhas de armazenagem como as tipo "Cíes".

A posição das decorações não é muito diversa, posto que os animais estão praticamente sempre de perfil, podendo ser mais ou menos realistas ou estilizadas, sobretudo no diz respeito às decorações com ictiomorfos e ornitomorfos. Contudo, parece não existir no NW uma tendência quer de esquematização, quer de realismo dos motivos zoomorfos ao longo da Idade do Ferro.

$\mathrm{Na}$ sua esmagadora maioria os motivos zoomorfos são elaborados por estampagem e impressão a partir de um estilete previamente idealizado pela pessoa ou pessoas incumbidas e tecnicamente capazes que estampavam sobre a peça o motivo, repetindo-o a espaços regulares por todo o diâmetro do vaso. Esse trabalho teria de ser efetuado por pessoas já bastante experientes na técnica de olaria.

Sendo mais próximos, ou não do realismo, o facto é que noutros suporte quer em gravação em pedra quer a ourivesaria pelo repuxado, ou pela cera perdida, o realismo dos animais é bastante mais notório do que na cerâmica.

\section{BIBLIOGRAFIA}

ABAD VIDAL, Emilio; REY CASTIÑEIRA, Josefa; ÁLVAREZ CASTRO, Gabriel; VARELA PET, José (2011) - Diseño y desarrollo de un modelo de datos para una IDE arqueológica de la Edad de Hierro en Galicia. En II Jornadas Ibéricas de Infraestructuras de Datos Espaciales. Barcelona 9, 10, 11 de novembro.

ALFAYÉ VILLA, Silvia (2010) - Iconografia Vaccea; una aproximación a las imágenes del território vacceo. De La región Vaccea A la Arqueología Vaccea. ROMERO.

ALMEIDA, Carlos Alberto Brochado de (1990) - Proto-História e Romanização da Bacia Inferior do Lima. Estudos Regionais, Número Especial, nº.7-8, Centro de Estudos Regionais, Viana do Castelo.

ARIZAGA CASTRO, Álvaro R.; FÁBREGA ÁLVAREZ, Pastor; AYÁN VILA, Xurxo M.; RODRÍGUEZ PAZ, Anxo (2006) - "A Apropiación Simbólica da Cultura Material Castrexa na Paisaxe Cultural dos Chaos de Amoeiro (Ourense, Galicia)". Cuadernos de Estudios Gallegos, LIII N.ำ119, pp. 87-129.

ARMADA, Xosé Lois, GARCÍA-VUELTA, Óscar (2015) "O machado figurativo de bronce da praia da Basteira (Cariño): novos datos para unha revisión.” Terras de Ortegal, 2, pp. 152-172.

AYÁN VILA, Xurxo M. (2012a) - Escavación arqueolóxica no Castro Grande de Neixón (Boiro, A Coruña). Campaña de 2005. Memoria Técnica. Laboratorio de Arqueoloxía da Paisaxe, Instituto de Estudos Galegos Padre Sarmiento. Santiago de Compostela.

AYÁN VILA, Xurxo M. (2012b) - Escavación arqueolóxica no Castro Grande de Neixón (Boiro, A Coruña). Campaña de 2007. Memoria Técnica. Laboratorio de Arqueoloxía da Paisaxe, Instituto de Estudos Galegos Padre Sarmiento, Consejo Superior de Investigaciones Científicas. Santiago de Compostela. Inédita.

BALSEIRO GARCÍA, Aurelia. (1994) - El oro en la provincia de Lugo. Servicio de Publicacións da Deputación Provincial de Lugo, Museo Provincial de Lugo. Lugo.

BETTENCOURT, Ana Maria dos Santos (1999) - A Paisagem e o Homem na bacia do Cávado durante o II e o I milénios AC, 5 vols. Braga, Universidade do Minho (Tese de Doutoramento - Policopiada).

BETTENCOURT, Ana Maria dos Santos (2000) - Estações da Idade do Bronze e Inícios da Idade do Ferro da Bacia do Cávado (Norte de Portugal). Cadernos de Arqueologia Monografias 11. Unidade de Arqueologia da Universidade do Minho, Braga.

CABANILLAS DE LA TORRE, Gadea (2015) - Arts et sociétés celtiques du Second Âge du Fer en Europe Occidentale: la céramique à décor estampé. Université de Paris I Panthéon - Sorbonne, Universidad Autónoma de Madrid. París - Madrid. 
CALO RAMOS, Nuria (1999) - Introducción ao estudio da decoración da cerâmica castreña. Un caso puntual: Borneiro. Trabalho de investigação de Doutoramento (1997-1999). Universidade de Santiago de Compostela. Santiago de Compostela. Inédito.

CONCHEIRO COELLO, Ángel (2008) - Castro do Achadizo. Cultura material, economía de subsistencia na Idade do Ferro. Memoria das escavacións 1991-1994. Caderno Cultural 11, Concello de Boiro. Boiro.

DINIS, António Pereira (1993) - Ordenamento do Território do Baixo Ave no I Milénio A.C. Tese de Mestrado apresentada à Faculdade de Letras da Universidade do Porto.

DINIS, António Pereira (2001) - O Povoado da Idade do Ferro do Crastoeiro (Mondim de Basto, Norte de Portugal). Cadernos de Arqueologia - Monografias 13. Unidade de Arqueologia da Universidade do Minho, Braga.

FERNÁNDEZ CARBALLO, Laureano (2003) - "Achega ó estudo dos ornitomorfos acuáticos da cultura castrexa galaica: anaco de fíbula indíxena ornado cun pato cullerete (Anas Clypeata). Gallaecia, 22, p. 143-155.

FIGUEIREDO, Sofia; NEVES, Dário (2015) - Quinhentas placas gravadas da Idade do Ferro do sítio fortificado do Castelinho (Nordeste Portugal): temas figurados e padrões de distribuição." Actas de Conferência: Congresso Internacional da IFRAO 2015, ARKEOS 37, (eds.) Collado Giraldo, H., García Arranz, J. J., pp. 1589-1605.

GARCÍA VUELTA, Óscar; PEREA CAVEDA, Alicia (2001) - "Las diademas-cinturón castreñas: el conjunto con decoración figurada de Moñes (Villamayor, Piloña, Asturias)". Archivo Español de Arqueología, 74, pp. 3-23.

LUENGO Y MARTINEZ, José María (1964) - "Machadinha votiva de Cariño, La Coruña." Revista de Guimarães, 74 (1-2), pp. 149-157.

MARTINS, Manuela (1987) - A cerâmica proto-histórica do Vale do Cávado: tentativa de sistematização. Cadernos de Arqueologia, Série II, 4, p. 35-77.

MARTINS, Manuela (1988) - O Povoado fortificado do Lago, Amares. Cadernos de Arqueologia, Monografias, 1, Braga.

MARTINS, Manuela (1990) - O Povoamento Proto-Histórico e a Romanização da Bacia do Médio Curso do Cávado. Cadernos de Arqueologia, Monografias, 5, Braga.

MARTINS, Manuela (1991) - O Povoado de Santo Ovídio (Fafe). Resultados dos trabalhos realizados entre 1980.1984. Cadernos de Arqueologia. Monografias, 6, Braga.

MEIJIDE CAMASELLE, Gonzalo, VILASECO VÁZQUEZ, Xosé Ignacio, BLASZCZYK, Jazek. (2009) - "Lousas decoradas con círculos, cabalos e peixes do Castro de Formigueiros (Samos, Lugo)." Gallaecia, 28, p. 113-130.

OLIVEIRA, Nuno Tiago Correia; BETTENCOURT, Ana Maria dos Santos (2020) - O povoado proto-histórico de
Santo António (Afife, Viana do Castelo): dados e reflexões sobre as suas materialidades. In CENTENO, Rui, MORAIS, Rui, SOEIRO, Teresa, FERREIRA, D. (Eds.), Cultura Castreja: Identidade e Transições. Vol. I. Santa Maria da Feira: Museu Convento dos Lóios / Câmara Municipal de Santa Maria da Feira.

PÉREZ OUTEIRIÑO, Bieito (1980) - Os ornitomorfos acuáticos no conxunto dos motivos decorativos da orfebrería castrexa. Boletín Auriense, 10, pp. 9-24.

Prehistoria. Arte Castrexa. Arte da Romanización. A Nosa Terra, Vigo, pp. 224-240.

REY CASTIÑEIRA, Josefa (2005a) - A metalurxia castrexa. In HIDALGO CUÑARRO, J. M. coord. Arte e Cultura de Galicia e Norte de Portugal. Arqueoloxía. Tomo II. Nova Galicia. Vigo, pp. 56-83.

REY CASTIÑEIRA, Josefa (1991) - Yacimientos castreños de la Vertiente Atlántica. Análisis de la cerámica indígena. Tese de Doutoramento. Universidade de Santiago de Compostela. Santiago de Compostela.

REY CASTIÑEIRA, Josefa (1995) - Cuestións de tipo territorial na Cultura Castrexa." In HIDALGO CUÑARRO, José Manuel; RODRÍGUEZ SOBRAL, José Manuel; DOMÍNGUEZ PÉREZ, M. eds. Actas del XXII Congreso Nacional de Arqueología. Vigo, 1993. Volumen II, Comunicacións de tema libre. Sección Xeralidades e Prehistoria (Continuación del Volumen I). Vigo, pp. 165-171.

REY CASTIÑEIRA, Josefa (1996) - Referencias de tempo na cultura material dos castros galegos." In HIDALGO CUÑARRO, José Manuel (coord.) (1996). A Cultura Castrexa galega a debate. Instituto de Estudios Tudenses. Tui, pp. 157-206.

REY CASTIÑEIRA, Josefa. (1998) - "Cerámica castrexa decorada.” In FÁBREGAS VALCARCE, Ramón; CARBALLO ARCEO, L. Xulio; ACUÑA CASTROVIEJO, Fernando (coords.).

REY CASTIÑNIRA, Josefa (2005b) - A cerámica castrexa. In HIDALGO CUÑARRO, J. M. coord. Arte e Cultura de Galicia e Norte de Portugal. Arqueoloxía. Tomo II. Nova Galicia. Vigo, pp. 84-108.

RODRÍGUEZ MARTÍNEZ, Rafael M. (2008) - Análise do material cerámico recuperado. In AYÁN VILA, Xurxo M. coord. Os Castros de Neixón (Boiro, A Coruña) II: de espazo natural a paisaxe cultural. Serie Keltia, Toxosoutos. Noia, pp. 150-229.

RODRIGUEZ PUENTES, Eugenio (1986) - La cerâmica estampillada castreña. (Aportácion a su estúdio). Tese para obtenção do grau de licenciado, apresentada à Universidade de Santiago de Compostela (policopiado).

RODRÍGUEZ PUENTES, Eugenio; TOMÁS BOTELLA, Víctor; ABAD GALLEGO, J. C. (1990-1991) - «Prospección y excavación arqueológica en Val Miñor: poblados fortificados». Castrelos, 3-4, p. 165-19o. 
SILVA, António Baptista (2006) - Proto-História e Romanização. O Baixo Minho. (Dissertação de Doutoramento em Arqueologia apresentada à Universidade do Porto).

SILVA, Armando Coelho Ferreira (1986) - A Cultura Castreja no Noroeste de Portugal. Museu Arqueológico da Citânia de Sanfins. Paços de Ferreira.
SILVA, Maria Antónia Dias (1997) - A Cerâmica Castreja da Citânia de Briteiros. Edição Sociedade Martins Sarmento, Guimarães.

SILVA, Maria Fátima Matos (2006) - O Povoamento Proto-Histórico e a Romanização da Bacia Superior do Rio Coura: Estudo, Musealização e Divulgação. Apresentada à Universidade de Granada (Tese de Doutoramento).

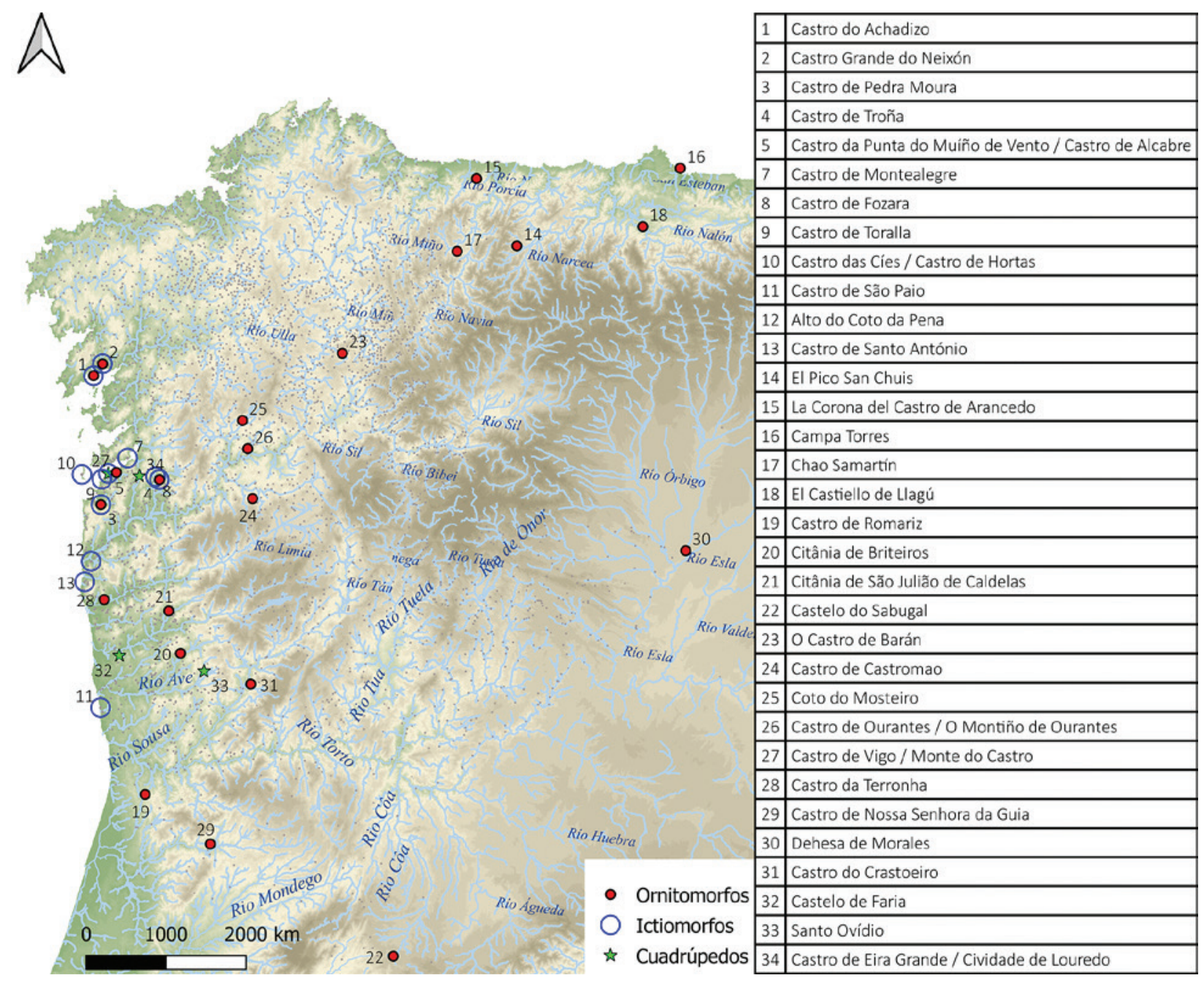

Figura 1 - Sítios arqueológicos considerados neste estudo. 

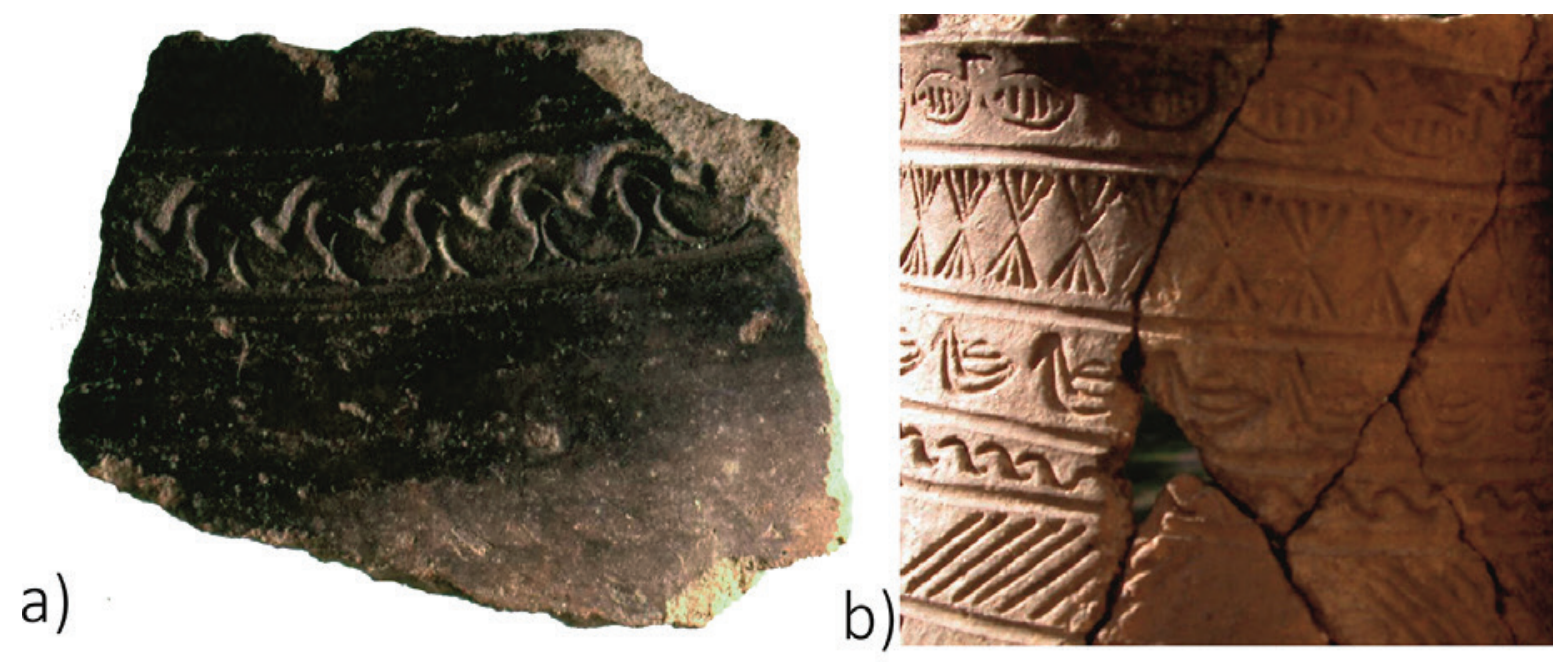

c)

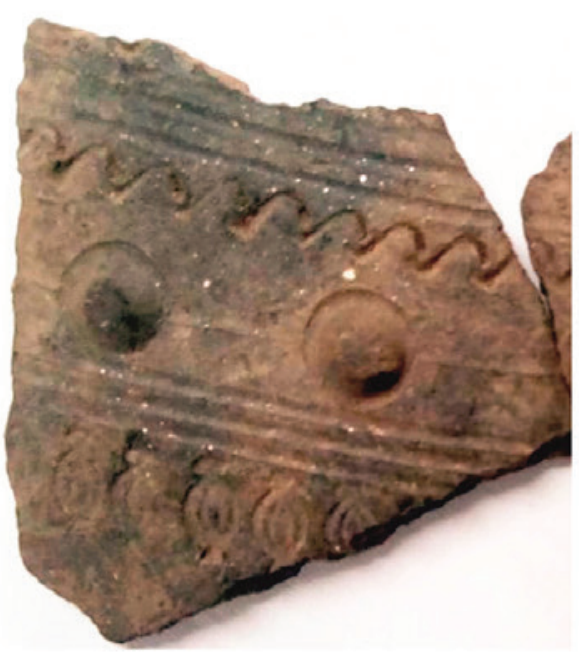

d)

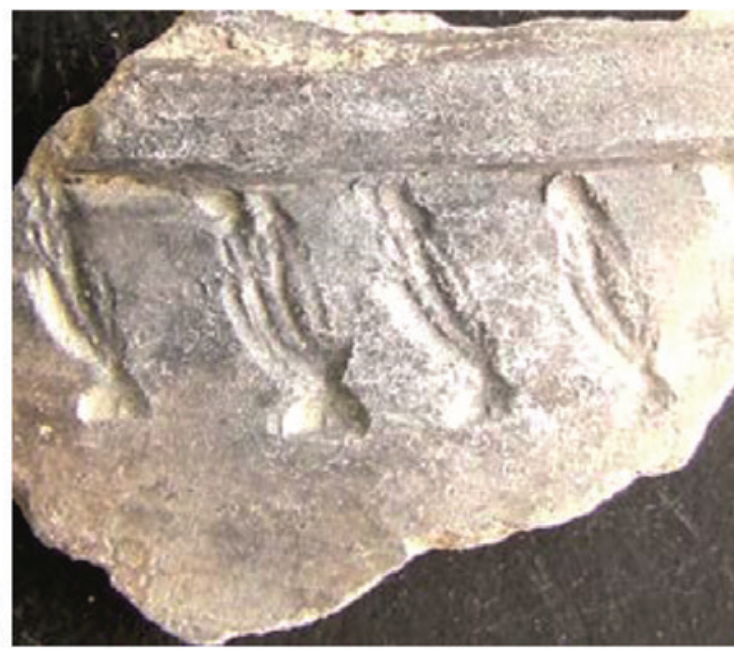

d)
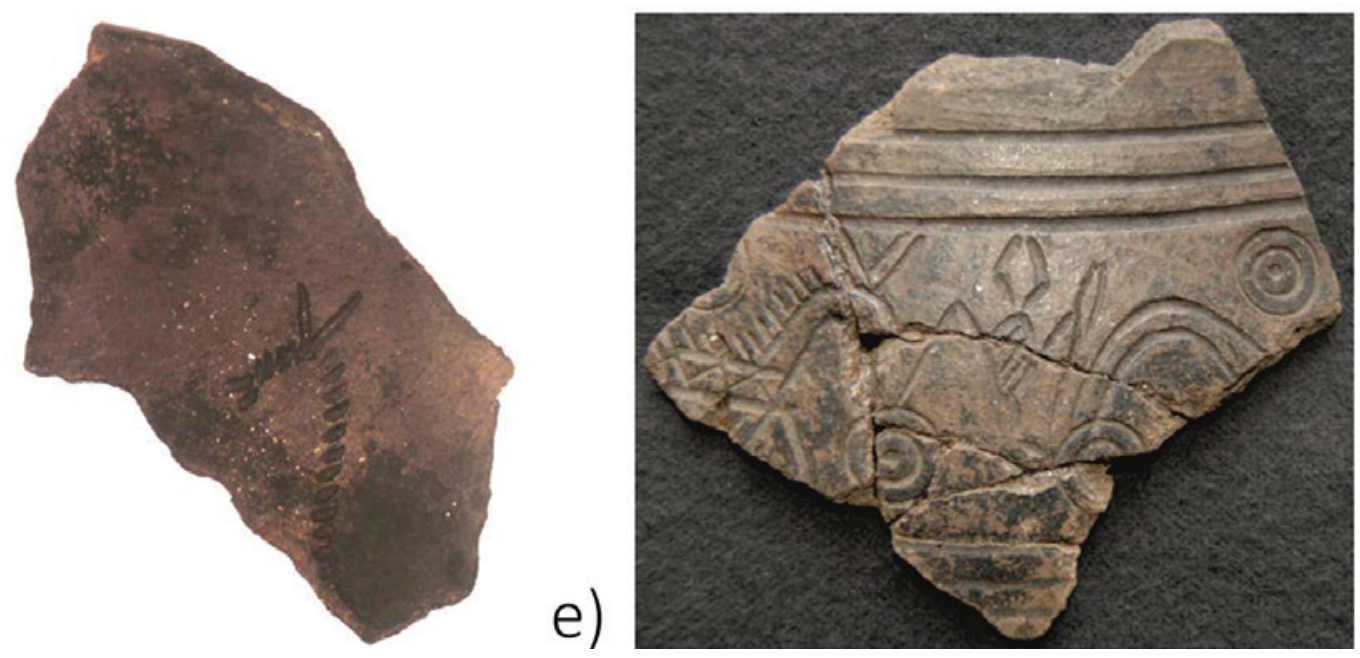

Figura 2 - Cerâmica com ornitomorfos: a) Castro de Vigo/Monte do Castro (Vigo, Pontevedra) (Foto: http://vigoarqueologico.blogspot.com/, modificada); b) Xerra tipo “Toralla” procedente do Castro Grande do Neixón (Boiro, A Coruña) (Foto: http://neixon.blogspot.com/, modificada). Cerâmicas com ictiomorfos: c) Castro do Achadizo (Boiro, A Coruña) (Foto: C. Seoane); d) Castro de Toralla (Vigo, Pontevedra) (Foto: P. Rey). Cerâmica com quadrúpedes: d) Castro de Santo Ovídio (Fafe, Braga) (Foto: X. Carballo); e) Castelo de Faria (Barcelos, Braga) (Foto: P. Rey). 


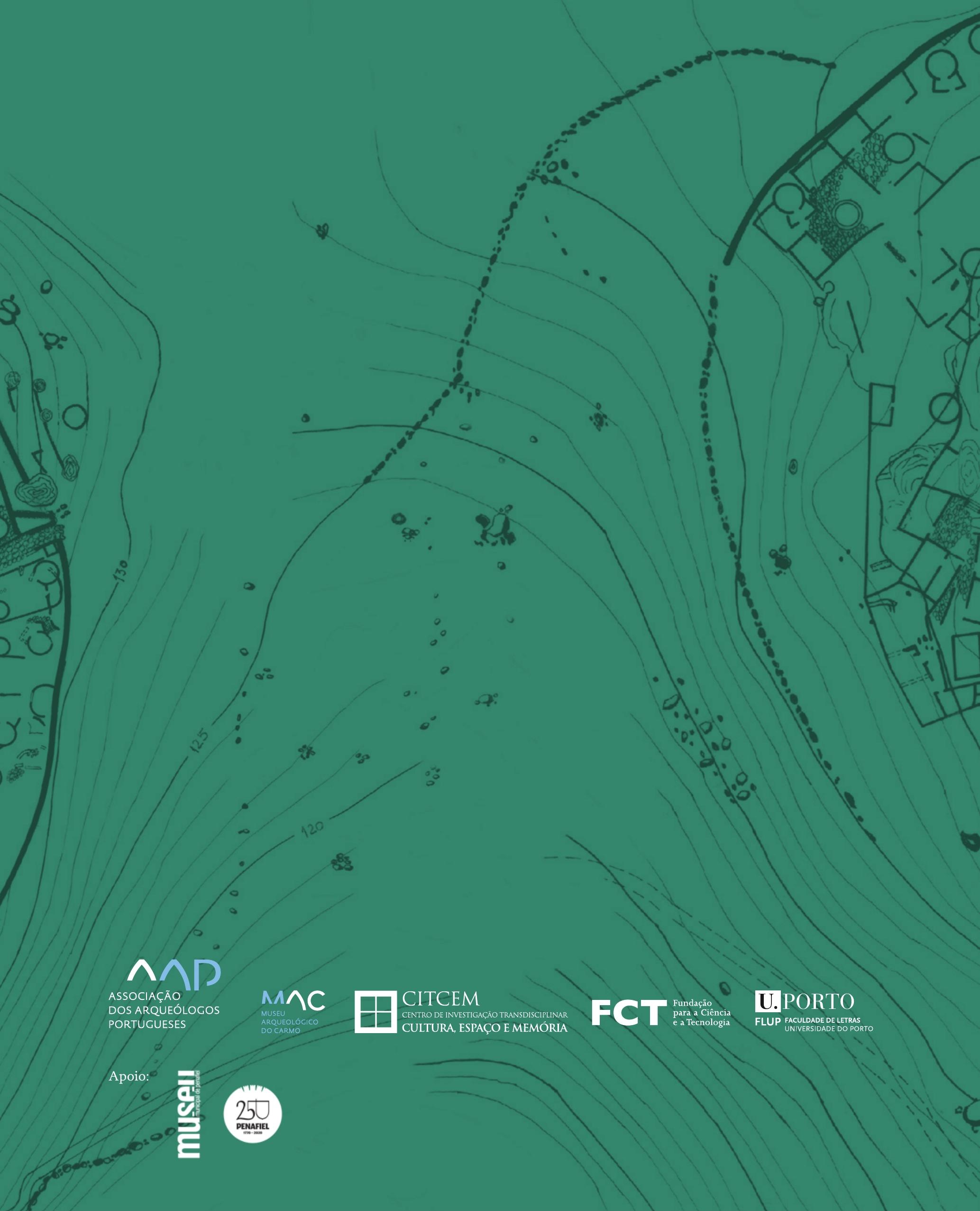

